\title{
Hemangiopericytoma of the Breast: A Case Report
}

\author{
Qingchao Tang Zhenning Wang Huimian Xu \\ Department of Surgical Oncology and General Surgery, The First Hospital of China Medical University, Shenyang, China
}

\section{Key Words}

Hemangiopericytoma: Diagnosis, Therapy

\section{Summary}

Background: Hemangiopericytoma (HPC) is a rare vascular tumor originating from the capillary pericytes, and HPC of the breast is extremely rare. Case Report: We describe a 50-year-old woman with HPC of the breast and focus on the diagnosis before operation and the extent of the operation. Under local anesthesia, a complete tumor excision was performed. Then, the fast-frozen material was pathologically examined and the diagnostic conclusion was 'malignant tumor of the breast, perhaps original from lobus intermedius tissue'. Finally, a modified radical mastectomy was performed, after which all 7 lymph nodes from the axillary fossa position of the excision showed symptoms of reactive hyperplasia. Conclusion: On the basis of reviewing the literature about the disease, we propose several basic ideas: an accurate biopsy together with an appropriate histological and immunohistochemical examination is promising, and since lymph node metastasis is extremely rare, a simple mastectomy may be considered.

\section{Introduction}

Hemangiopericytoma (HPC) is a rare vascular tumor originating from the capillary pericytes, which are contractile spindle cells surrounding the capillaries and postcapillary venules [1]. It was first described by Stout and Murray in 1942 as Zimmermann's pericytes which proliferate in the vessel wall [2]. Since

\author{
Schlüsselwörter \\ Hämangiopericytom: Diagnose, Therapie
}

\section{Zusammenfassung}

Hintergrund: Das Hämangiopericytom (HPC) ist ein seltener vaskulärer Tumor, der aus kapillären Pericyten stammt. Ein HPC der Brust ist extrem selten. Fallbericht: Wir beschreiben eine 50-jährige Frau mit einem HPC der Brust und schildern insbesondere die präoperative Diagnose und das Ausmaß der Operation. Unter Lokalanästhesie wurde eine vollständige Tumorentfernung vorgenommen. Danach erfolgte eine pathologische Untersuchung auf Basis der Schnellgefrier-Methode, die zur Diagnose "bösartiger Tumor der Brust, vielleicht aus Gewebe der mittleren Brust stammend" führte. Schließlich wurde eine modifizierte radikale Mastektomie durchgeführt, wobei alle 7 Lymphknoten der Entnahmeposition in der Fossa axillaris Symptome einer reaktiven Hyperplasie zeigten. Schlussfolgerung: Auf der Basis der relevanten Literatur schlagen wir eine Reihe von Grundideen vor: Eine sorgfältig durchgeführte Biopsie zusammen mit einer entsprechenden histologischen und immunhistochemischen Untersuchung ist vielversprechend, und da Lymphknotenmetastasen sehr selten sind, kann eine einfache Mastektomie in Erwägung gezogen werden.

then, some cases of HPC in various locations of the body such as the lower extremities, meninges, pelvis, retroperitoneum, trunk, upper extremities, uterus, orbit and oral cavity have been reported [3]. Among these cases, HPC of the breast is extremely rare. Since it is nonspecific in most routine examinations [1], when diagnosing this disease, a pathological or even immunohistochemical examination may be necessary. In

\begin{tabular}{ll}
\hline KARGER & ( ) 2008 S. Karger GmbH, Freiburg \\
Fax +497614520714 & Accessible online at: \\
Information@Karger.de & www.karger.com/brc \\
www.karger.com &
\end{tabular}


this case report, first, we describe a 50-year-old woman who presented with a mass in her breast. We mainly describe the clinical, mammographic and pathological aspects. Second, we propose some of our opinions on this disease regarding diagnosis and therapy.

\section{Case Report}

On March 27, 2007, a 50-year-old woman was admitted to our hospital with a persistent augmenting mass in the left breast. The mass was painless and without nipple discharge or hemorrhage. The patient said the mass had enlarged very quickly. It was only about $2 \mathrm{~cm} \times 1 \mathrm{~cm}$ when she found the mass about 20 days before she came to our hospital. Her medical history and family history were unremarkable. Physical examination revealed an approximately $5 \mathrm{~cm} \times 5 \mathrm{~cm}$ round firm mass at the 10 o'clock position of her left breast, which was painless and without local skin impaction. A lymph node about $1 \mathrm{~cm} \times 1 \mathrm{~cm}$ was palpable in the left axillary fossa, which was movable and painless. Mammography revealed a 39.5 $\mathrm{mm} \times 37.6 \mathrm{~mm}$ well-circumscribed mass at the 10 o'clock position of the left breast (fig. 1).

Since the tumor had enlarged very quickly and there was a palpable lymph node in the axillary fossa, we performed a complete excision of the tumor under local anesthesia. Then, a fast-freezing pathological examination of the tumor was made and led to the diagnostic conclusion of a 'malignant tumor of the breast, perhaps original from lobus intermedius tissue'. Thereafter, we performed a modified radical mastectomy. During the operation, we subjected the palpable lymph node to another fastfreezing pathological examination and reported a 'reactive hyperplasia of the lymph node'.

After the operation, we took seven lymph nodes from the axillary fossa position of the excision, which were sent to a systematic pathological examination together with the tumor. The tumor was $5 \mathrm{~cm} \times 4 \mathrm{~cm} \times 4 \mathrm{~cm}$, colored grey and yellow in cross-section, without muscle or skin infiltration. We saw neither necrosis nor calcification of the tumor. The seven lymph nodes were soft without any obvious evidence of metastasis. Histological examination of the mass is shown in figure 2. All the lymph nodes showed symptoms of reactive hyperplasia. Immunohistochemical examination suggested that the tumor was positive for CD34 and negative for vimentin, desmin, actin, s-100 and CK (fig. 3).

\section{Discussion}

HPC of the breast is extremely rare, but its malignant potential is diverse. Therefore, the prognosis of this disease is diverse as well [5]. Currently, there are no guidelines available how to treat a hemangiopericytoma. On the basis of reviewing some pertinent literature, we would like to discuss some problems concerning the diagnosis and the therapy.

\section{Diagnosis}

Since it is not specific in most routine breast examinations, including ultrasound, mammography, biochemical or even traditional pathological examination, it is very difficult to thoroughly diagnose this disease before the operation. Moreover, predicting the biologic behavior of HPC based on cytotoxic features is not yet feasible [6]. Core biopsy may be useful in dealing with this disease. There was once a case reported by

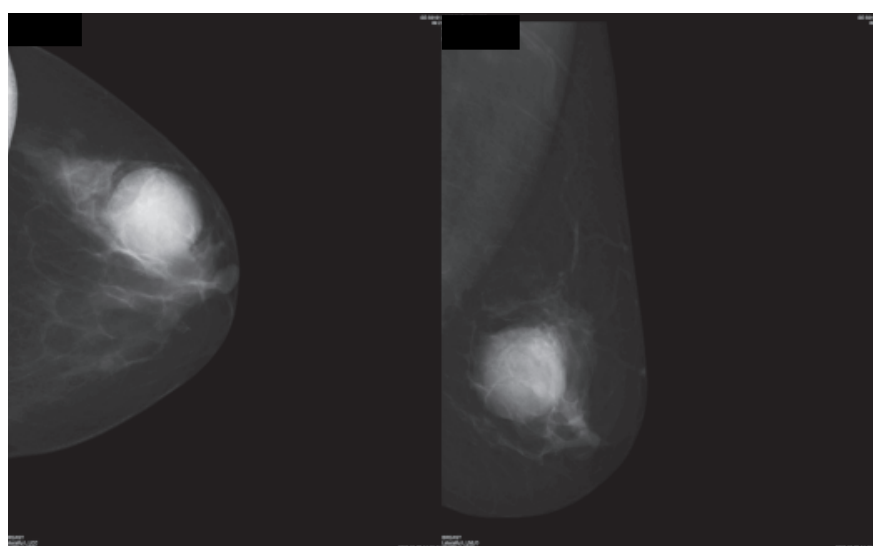

Fig. 1. A $39.5 \mathrm{~mm} \times 37.6 \mathrm{~mm}$ well-circumscribed mass at the 10 o'clock position of the left breast. There was no calcification.

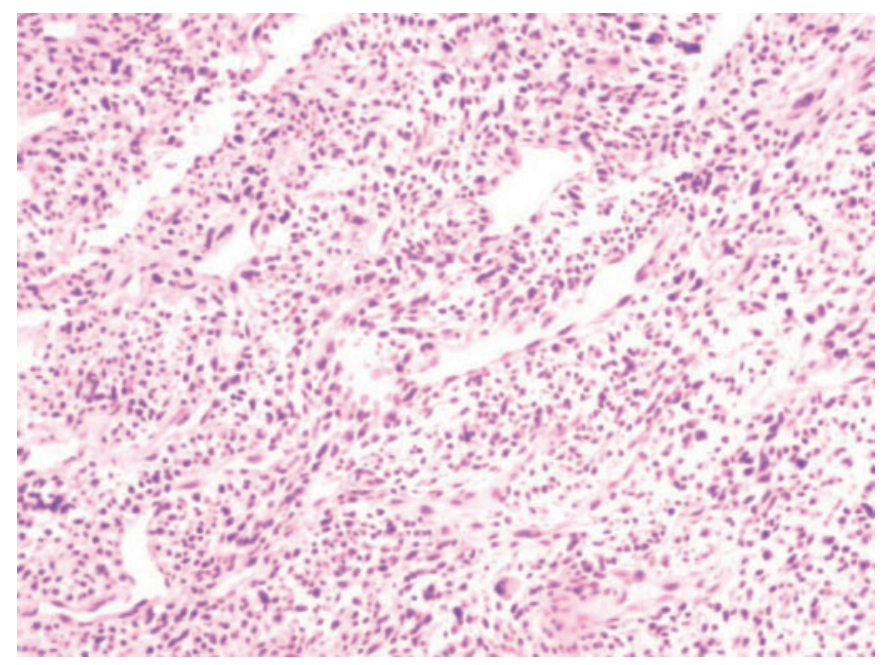

Fig. 2. Many spindle and oval cells surrounded the capillaries, which include karyomegaly anachromasis and less cytoplasm (Hematoxylin/eosin, $\times 100)$.

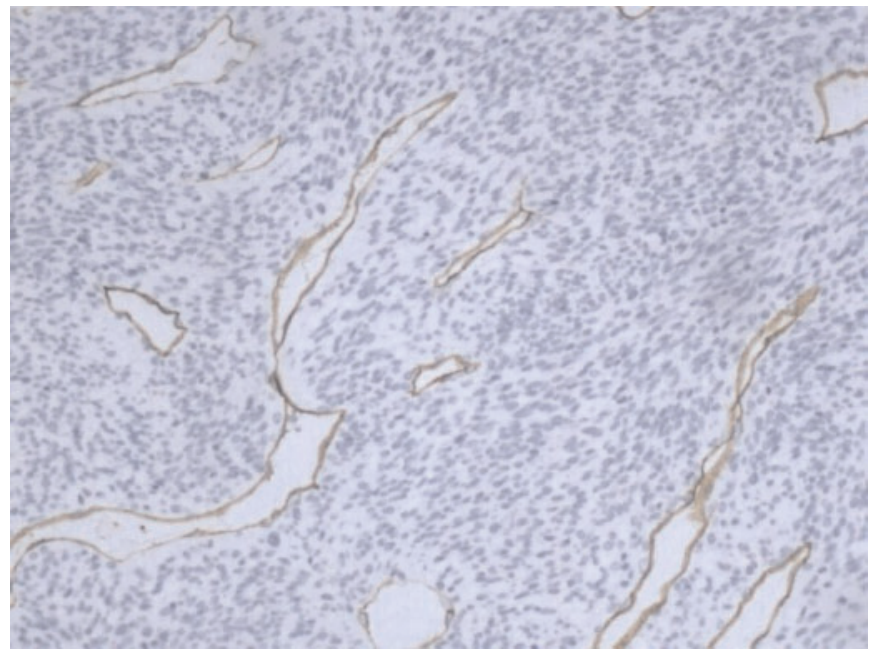

Fig. 3. Expression of the vascular marker CD34 $(\times 100)$. 
Buecker et al. [4]: In 2004, a female patient was sent to the hospital and a lump was found in her breast. Then, a core biopsy was performed, but no malignant tissue was found. So they did not treat the tumor. In 2006, since the tumor had enlarged very quickly, another ultrasound-guided core biopsy was performed, with histological and immunohistochemical findings consistent with malignant hemangiopericytoma. Then, the patient underwent a modified radical mastectomy operation [4]. In contrast, as for our patient, we performed a complete excision under local anesthesia for the following reasons: First, the tumor was superficial so that it was easy to excise in its entirety, and the damage was small. Second, the tumor grew very fast, which prognosticated a malignant possibility. Third, there was a palpable lymph node in the axillary fossa before the operation, which also prognosticated a malignant possibility. However, the fast-freezing pathological examination could not definitely diagnose HPC of the breast and it could only be reported as a 'malignant tumor of the breast, perhaps original from lobus intermedius tissue'.

In conclusion, we think that perhaps only an accurate biopsy together with an appropriate histological and immunohistochemical examination may be useful to diagnose this disease.

\section{Therapy}

Operation: Kanazawa et al. [7] thought that the extent of surgery depends on tumor size and breast size. In general, lymph node metastases are rare, so complete axillary lymph node dissection does not seem to be necessary [7]. In our case, a modified radical mastectomy was performed on the patient and, as a result, no metastases in the lymph nodes from the axillary fossa position of the excision were found after the operation. This supports the opinion of Kanazawa. However, in order to form guidelines to treat this disease, more cases and systemic clinical trials are needed.

Radiotherapy: According to the research of Chugh and Baker [8], under some circumstances radiotherapy is recommended, for example if the tumor is more than $2 \mathrm{~cm}$ in diameter, after incomplete resection, or for tumor reduction before surgery. But there is no authoritative evidence to demonstrate that radiotherapy is necessary for HPC of the breast. As for this patient, we performed a modified radical mastectomy which had a negative surgical margin. Similarly, radiotherapy has side effects, so we did not suggest the patient to have radiotherapy. Chemotherapy: The role of adjuvant chemotherapy is controversial for patients with soft-tissue sarcomas in general, and even less defined in patients with hemangiopericytoma [9]. Follow-up: For HPC all over the body, recurrence and metastasis are not rare [3]. Although they are not very common for HPC in the breast, we think a lifetime follow-up is necessary. One study suggested that positron emission tomography imaging may be useful for the detection of recurrent HPC during the follow-up [10].

\section{References}

1 Lorigan JG, David CL, Evans HL, Wallace S: The clinical and radiologic manifestations of heman giopericytoma. AJR Am J Roentgenol 1989;153 345-349.

2 Stout AP, Murray MR: Hemangiopericytoma: A vascular tumor featuring Zimmermann's pericytes. Ann Surg 1942;116:26-33.

3 Enzinger FM, Smith BH: Hemangiopericytoma. An analysis of 106 cases. Hum Pathol 1976;7:61-82.

4 Buecker B, Kapsimalakou S, Stoeckelhuber BM, Bos I, Wulf-Brodnjak S, Fischer D: Malignant hemangiopericytoma of the breast: a case report with a review of the literature. Arch Gynecol Obstet 2008;277:357-361.
5 Coarasa-Cerdán A, Palomo-Jimenez M, MonteroMontero A, Alegre-Bernal N, Guadaño-Salvadores V: Hemangiopericytoma of the breast: Mammographic and sonographic findings. J Clin Ultrasound 1998;26:155-158.

6 Chhieng D, Cohen JM, Waisman J, Fernandez G, Cangiarella J: Fine-needle aspiration cytology of hemangiopericytoma: A report of five cases. Cancer 1999;87:190-195.

7 Kanazawa N, Ono A, Nitou G, Ueno E, Fujiwara M, Kamma H, Izumiya N, Fukao K: Primary malignant hemangiopericytoma of the breast: report of a case. Surg Today 1999;29:939-944.
8 Chugh R, Baker L: Nonepithelial malignancies of the breast. Oncology 2004;18:665-676.

9 Sarcoma Meta-Analysis Collaboration: Adjuvant chemotherapy for localised resectable soft-tissue sarcoma of adults: Metaanalysis of individual data. Lancet 1997:350:1647-1654.

10 Kim JY, Chang BC, Ha JW: Images in cardiology. Intimal angiosarcoma of the descending aorta as an unusual cause of severe upper extremity hypertension. Heart 2006;92:306. 